\title{
ANALYSIS OF THE COMPETITIVENESS OF INDONESIA TOURISM PRICE COMPARED TO THE COMPETITORS (DEMAND ELASTICITY APPROACH)
}

\author{
${ }^{1}$ Rayinda Citra Utami, ${ }^{2}$ Djoni Hartono, ${ }^{3}$ Agni Alam Awirya \\ ${ }^{1}$ Ministry of Tourism \\ Jl. Medan Merdeka Barat No.17, Jakarta - Indonesia. \\ ${ }^{2}$ Department of Economics - Faculty of Economics and Business - Universitas Indonesia \\ Gedung Departemen Ilmu Ekonomi - FEBUI. Kampus UI Depok 16424. Jawa Barat - Indonesia. \\ ${ }^{3}$ Bank Indonesia \\ Jl. Kapten Maruli Sitorus no 8, Sibolga - Sumatera Utara \\ Correspondence E-mail: agniiesp89@gmail.com
}

Recieved: January 2016; Accepted: June 2016

\begin{abstract}
This study applies Almost Ideal Demand System models to examine Indonesia's competitiveness as a tourist destination compared to two main competitor countries. The model was used to estimate the sensitivity of tourism demand from seven tourist-main market countries to price changes, the tourists' total budget and global economic crisis. The model estimated result meets the assumptions of the demand theory: homogeneity and symmetry. The elasticity price shows that Indonesia is more competitive than Thailand among Australian and American tourists; while Indonesia is more competitive than Malaysia among American tourists. The research result also shows that the tourism price is the main determinant affecting the allocation of tourist expenditure in the three destinations.
\end{abstract}

Keywords: EC-LAIDS model; Indonesia; price competitiveness; tourism demand elasticity JEL Classification: D4, Z32

\section{Introduction}

The tourism sector is one of the fast growing economic sectors in the world. The total number of foreign tourists visiting the whole world is experiencing a rapid growth, from 25 million people in 1950 to 1.04 billion in 2012, as well as domestic tourists reach $5-6$ billion people (World Tourism Organization/UNWTO, 2013b). The challenges faced by tourism sector in recent years, such as the global economic crisis, the rising of oil prices, natural disasters and terrorist attacks do not greatly affect the tourism sector. It can be seen that tourism sector still contributes significantly to the growth of the world economy, including a $9 \%$ contribution to GDP, $6 \%$ of total exports and is capable of creating one of 11 new jobs (UNWTO, 2013a).

The more competitive a country as a tourist destination, the more tourists will be attracted and spend more money in the tourist destination country; and consequently will increase the GDP and the country's economic growth, which means that the economic welfare of the local community will increase. Therefore, every country will be competing to attract more tourists and spending (Crouch \& Ritchie, 1999; Dwyer et al, 2000).

UNWTO (2011) predicts that the number of foreign tourists will increase by an average of 3.3\% annually from 2010 to 2030 and will reach 1.8 billion tourists by 2030. Asia Pacific is predicted to become a tourist destination with the highest 


\section{Jurnal Ekonomi Pembangunan, 17 (1), Juni 2016, 108-124}

growth rate of tourist arrivals reaching $4.9 \%$ per year and the market share increased from $22 \%$ in 2010 to $30 \%$ in 2030 .

Southeast Asia as the second largest market share in the Asia Pacific region, after South Asia, is predicted to increase market share and tourist growth of 5.1\% (UNWTO, 2011). This growth rate is even above the average tourist growth projections for Asia Pacific and the World in the period 20102030. Indonesia has a significant potential to develop into a world tourist destination country, especially leisure travel. WEF in Blanke and Chiesa (2013) put Indonesia on the 6th and 38th of 140 countries in the world respectively for the ownership of natural resources and culture. This rating is well above neighboring countries, such as Thailand and Malaysia.

However, having potential natural resources and great culture, Indonesian tourism has not achieved their optimal achievement. Since the global economic crisis in 2008, tourist arrivals and total tourist spending in Indonesia tend to be slowed. Similarly, the Indonesian market share to total visits and tourist spending in Southeast Asia continues to decline. In fact, the market share of the Southeast Asian travelers to the world tends to increase. This condition indicates a decrease in competitiveness of Indonesian tourism.

This study is aimed to:

First, investigate the main determinants of expenditure allocation from the seven tourist main market countries to the three tourist destination countries (Indonesia, Thailand, and Malaysia). Second, estimate the demand elasticity to see how sensitive the tourist demand to the price changes, the changes in tourist revenue and the effect of the global economic crisis. Third, analyze the price competitiveness of Indonesian tourism compared to the two main competitors in the eyes of tourists from different markets.

Previous studies on tourism competitiveness can be grouped into two major groups: studies related dimensions and studies related research models. One comprehensive research specifically analyzing price competitiveness is a study conducted by Dwyer et al (2000). However, Dwyer et al (2000) did not analyze how the price competitiveness affects the amount of foreign exchange earned from tourist spending in each destination. Dwyer et al (2000) used several stages to construct the indexes without doing econometric techniques.

Several studies related to research models are studies done by Lyssiotou (2000), Durbarry \& Sinclair (2003), Li et al (2004), Cortez et al (2009) and Mangion et al (2005). They applied static AIDS and dynamic AIDS (EC-LAIDS) which were estimated by SUR, 3SLS, FIML or NLS methods. Most studies applying AIDS demand system model are analyzing the tourists demand in Europe. The result shows that foreign tourists demand is sensitive to the price, but the degree of its sensitivity varies according to the countries of origin and tourist destinations.

Two literatures applying AIDS model to analyze tourism competitiveness are Mangion et al (2005) and $\mathrm{Li}$ et al (2013). Mangion et al (2005) concluded that the level of price sensitivity of British tourists demand varies for each destination in the Mediterranean region; so it is important for each destination to monitor relative price competitiveness between these destinations to attract more tourists' spending. However, Mangion et al (2005) did not give an idea of relative competitiveness of a particular destination from the standpoint of tourists from different markets.

A Research done by Li et al (2013) bridged the gap. Li et al (2013) analyzed the price competitiveness of Hong Kong as an international tourist destination compared to competitor countries (Macau, Singapore and South Korea), from the viewpoints of tourists from Australia, China, Japan, Taiwan, the UK and the US. The study concluded that the competitiveness level of Hong Kong against the competitors varies for each tourist market country. Overall, Hong Kong is more competitive than Macau, especially 


\section{Jurnal Ekonomi Pembangunan, 17 (1), Juni 2016, 108-124}

from the perspective of Australian and Chinese tourists; and is less competitive than Singapore and South Korea.

Reseach on the competitiveness of tourism price in relation between the price and its effects on the tourists' budget share in destination countries, particularly in the Asian region is not much to be found. One most detailed study was conducted by Wang and Wu (2003). However, the budget share in this study is only proxied by the proportion of visitor share, making it less able to capture the tourism revenue in the true sense. This study analyzed the tourism competitiveness of Taiwan towards 6 main competitors (Hong Kong, Singapore, Malaysia, Thailand, Indonesia dan Phillipines), from the point of view of Japanese and American tourists. A simple ordinary simultaneous regression model is applied in this study, so that the estimation result does not meet the demand assumptions. The result of the study shows that the logo of Visit Malaysia Year launched in 1990 significantly affected the visit of Japanese and American tourists to Malaysia. Political and social crises in Phillipines (19831994) negatively affected the American tourists' visits to Phillipines, Singapore and Indonesia. For US travelers, Malaysia-Thailand, IndonesiaPhilippines, and Taiwan-Hong Kong are complementary destinations; while Hong KongPhilippines is a substitution destination.

Travelling is a preference for consumers. Once a travel decision is made, consumers choose from various tourist destinations, with various substitution degrees. Travelers are faced with time and income problems. This fact underlines the theory that choosing tourist destinations is consumers' preferences.

It is assumed that travelers are faced with several alternative destinations; next they choose a particular destination to maximize its utilities. Utilities are obtained from their spending time in a tourist destination. Utilities are derived from attributes owned by the tourist destinations, such as natural beauty, suitable climate and other social-cultural features. These attributes are consumed together with other goods and services available at the tourist destination.

The tourists' utility function that shows their preferences is assumed to be weakly separable. The concept of separability illustrates that consumers allocate their spending into a group of commodities in a multi-stage process of budgeting; that preference in each commodity group is independent or is not influenced by demands on the other commodity groups. This assumption is valid as long as the commodities within one group have linkages (to be complements or substitutes). In the context of tourism, substitution or complementary between destinations depend on the similarity of the tourism attributes possessed, tourist consumption patterns or geographic proximity.

In this study, tourists are assumed to allocate their total budget in 4-stage process. The first stage, tourists from 7 major market countries; those are short-distance travelers (Singapore, Malaysia, Australia, Jepan and China) and longdistance travelers (England, and United States) will determine the amount of money they have for travel spending not travel expenses. The second stage, tourists will decide to travel abroad or in the country. The third stage, tourists will split their international travel spendings within three destination countries: Indonesia, Thailand and Malaysia, and other destination countries. The fourth stage, tourists will allocate their spendings between destinations in Indonesia, Thailand and Malaysia.

This study focuses on the 4th stage of the budget allocation process. The decision of tourist expenditure allocation in the three destinations (Indonesia, Thailand and Malaysia) is only influenced by the total spending and the tourism price of the third destinations. This means the decision is independent towards the condition of other tourist destinations (in addition to the three countries), in the tourists' country of origin and is also independent of the expenditure amount in addition to travel. 


\section{Jurnal Ekonomi Pembangunan, 17 (1), Juni 2016, 108-124}

The competitiveness of a tourist destination is a concept covering price differences which is adjusted to the exchange rate movements, the productivity level of various components in tourism industry and other qualitative factors that influence the attractiveness of a tourist destination (Forsyth \& Dwyer, 2009). Price competitiveness is a major component in the overall competitiveness of a tourist destination. The total costs incurred by tourists include the cost of transportation to and from tourist destinations as well as the amount spent during at tourist destinations, including: accommodation, tour packages services, food and beverages, entertainment, etc. The total price determines tourists' decision to travel to a particular destination (Dwyer et al, 2000).

Tourism competitiveness essentially related to tourist spending ( $\mathrm{Li}$ et al, 2013). Ritchie and Crouch (2003) states that what makes a tourist destination truly competitive is its ability to increase tourist expenditure, and attracting more tourists, which in turn will increase the earnings of tourism foreign exchange. However, the low price level does not guarantee the higher revenue of a tourism destination. If the demand for a destination is inelastic to price, then the price reduction strategy would not able to increase foreign exchange earnings of the destination. Therefore, the demand elasticity approach is used to measure the competitiveness of tourism in terms of price.

This study analyzes the competitiveness through demand elasticity approach. The demand analysis is widely used in research related to tourism development efforts. Deluna and Jeon (2014) applied demand analysis to estimate the determinants of foreign tourist arrivals. The result of the study became an input to the tourism development strategy in the Philippines. Meanwhile, (Moorthy 2014) also used demand analysis to determine key factors of tourist destination preference in Malaysia. This research became one of the inputs for the Malaysian tourism promotion.

The focus of this study is the use of a demand systems approach and Almost Ideal
Demand System (AIDS) model to analyze the competitiveness in relation to demand elasticity. AIDS models can analyze changes in travelers' expenditure allocations in various alternative destinations. Because, based on consumer demand theory, the estimation result of AIDS model is expected to meet the assumptions of the demand theory.

In the long-term condition (balance), tourists are always able to adjust their spending towards the changes of price and income. Meanwhile, in reality, several factors such as a tendency of repeat visits (repeater), unstable preferences, imperfect information, adjustment cost, unappropriate expectations, and misinterpretations of real price changes in adjusting their spending, will cause the tourists cannot adjust perfectly to the changes in price and income. Therefore, until the perfect adjustment, tourists are no longer in equilibrium (out of equilibrium). This condition causes static AIDS modeling does not meet the assumptions of demand theory (Li et al, 2004). In addition, static AIDS model also does not account the dynamics (nonstasioneritas data) that often arise in the time series analysis. This is what lies behind the use of dynamic models specifications by applying cointegration techniques and Error Correction Mechanism (ECM) in this study.

This study is expected to address the gap in the limitations of the tourism literature review regarding price competitiveness, particularly in South-east Asia. Leaning on consumer demand theoretical framework, the use of AIDS model in this study is appropriate to capture the changes in the tourists' spending allocation, which could give a signal to the economic performance (the supply side) of the third alternative destination countries: Indonesia, Thailand and Malaysia. In this study, the competitiveness is analyzed in relation to the demand elasticity, connecting between the supply and demand of the competitiveness. For each tourist market country, the demand elasticity for Indonesia and its competitors is estimated and the results are compared to all the market countries. The result 


\section{Jurnal Ekonomi Pembangunan, 17 (1), Juni 2016, 108-124}

of this ratio is used to analyze how successful a destination can increase their demand compared to competitors.

\section{Methods}

Estimating the tourists' demand system with LAIDS and EC-LAIDS models are done to answer the purpose of the research. Next, the restrictions on the EC-LAIDS model related to demand theory assumptions to be met is done. Then, restriction validity test is conducted to test whether the model really satisfies the assumptions of the demand theory.

To answer the first objective of this study, the EC-LAIDS model estimation is carried

$w_{i t}^{O}=\alpha_{i}^{O}+\sum_{j} \gamma_{i j}^{O} \ln p_{j t}^{O}+\beta_{i}^{O} \ln E_{t}^{O}+\phi_{i}^{O} D_{t}^{O}+\varepsilon_{i t}^{O}$

Where:

$w_{i t}$ : budget share, that is the expenditure proportion allocated by traveler originated from a particular country $O$ to a destination country $i$ on particular time $t$.

$p_{j t}:$ tourism price (effectively relative) on each destination $j$ on particular time $t$.

$E_{t}$ : real per capita expenditure of travelers originated from certain country $O$ to the three mentioned destinations on particular time $t$.

Tourists' real per capita expenditure is travelers' per capita expenditure deflated by Stone price index, $\ln P_{t}^{*}=\sum_{i} w_{i t} \ln p_{i t}$.

$D_{t} \quad$ : dummy variabel of time capturing the effects of global economic crisis.

$\alpha_{i}, \gamma_{i j}, \beta_{i}, \phi_{i}:$ parameter to be estimated.

$i, j=1,2,3$ (1=Indonesia, $2=$ Thailand, $3=$ Malaysia) $O=$ market country/tourists' origin (Singapore, Malaysia, Australia, Jepan, China, United Kingdom and United States out. Previously, the LAIDS model is estimated to ensure the existence of a cointegration relationship between the variables in the model and to calculate the ECT variables to be included as one of the independent variables in the ECLAIDS model.

\subsection{Linear Almost Ideal Demand System (LAIDS) Model Specifications}

The LAIDS model for tourist demand to the three destination countries: Indonesia, Malaysia and Thailand from seven tourist market countries (Singapore, Malaysia, Australia, Japan, China, UK and USA) is as follows:

$t=2005,2006, \ldots, 2012$

$\varepsilon_{t}:$ error term on time $t$.

The above model follows the AIDS model specifications developed by Deaton \& Muellbauer (1980) by adding dummy variables crisis that is supposed to influence the tourist demand, as is done by De Mello et al (2002). There are 7 demand systems for each origin. Each system consists of three equations for each destination, except for Malaysian tourists demand system consisting of only two equations; because the focus of this study is the foreign tourists and is not domestic tourists.

\subsection{Error Correction-Linear Almost Ideal Demand System (EC-LAIDS) Model Specifications}

The EC-LEDS model for tourist demand to three destination countries, namely Indonesia, Malaysia and Thailand from seven tourist market countries (Singapore, Malaysia, Australia, Japan, China, UK and USA) is as follows (Wu et al, 2011):

$\Delta w_{i t}^{O}=\alpha_{i}^{*}+\sum_{j} \gamma_{i j}^{*} \Delta \ln p_{j t}^{O}+\beta_{i}^{*} \Delta \ln E_{t}^{O}+\lambda_{\mathrm{i}} \mathrm{ECT}_{i t-1}+\phi_{i}^{*} D_{t}^{O}+\varepsilon_{i t}^{*}$ 


\section{Jurnal Ekonomi Pembangunan, 17 (1), Juni 2016, 108-124}

where:

$\Delta$

ECT $_{i t-1} \quad:$ residual lag of LAIDS model equation (3.1)

$\alpha_{i}^{*}, \gamma_{i j}^{*}, \beta_{i}^{*}, \lambda_{i}, \phi_{i}^{*}:$ parameter to be estimated

$\varepsilon_{t}^{*} \quad:$ error term on time $t$

For each origin, EC-LAIDS model is estimated to know which determinant (price, real spending, dummy) significantly affects the tourists' spending allocation to the three destinations.

The parameters of LAIDS and EC-LAIDS demand system models are estimated by multivariate regression analysis: the Seemingly Unrelated Regression (SUR) method. The SUR method with the Generalized Least Square (GLS) approach is appropriately applied when all the independent variables are assumed exogenous and the errors are heteroskedastis and are correlated between equations in a system (Eviews 6 User's Guide II, 2007).

Before estimating the EC-LAIDS model, stationarity and cointegration tests are necessary to be done. The stationarity test is needed to ensure that all variables in the model have a long-term trend. In econometrics, intuitively, a model has a long-term trend if each variable is non-stationary in the levels, but is stationary in first difference level, or is integrated in the order 1, I (1). Cointegration test is conducted by EngleGranger test. It is done by testing the stationarity of residual LAIDS model. The stationarity test used is Dickey-Fuller GLS test, because the test statistic is more robust in small samples condition, compared to other root unit tests such as Augmented Dickey -Fuller or Phillips-Perron (Li et al, 2013). If the residual is stationary on a level, this means all the variables in the model cointegrated, or in other words have a relationship or a long-term equilibrium (Nachrowi and Usman, 2006).
Furthermore, the EC-LAIDS model is estimated by inserting the error correction term (ECT) as an independent variable, which is measured as a residual lag of LAIDS model, where the other dependent and independent variables (except dummy variables) are in the form of the first distinction. ECT coefficient is expected to be significant and negative, for the correction takes place or the adjustment of short-term imbalance towards $w_{t}$ leads to long-term trend.

In accordance with the theoretical framework of the demand theory, EC-LAIDS model must meet three main assumptions; those are adding-up, homogeneity and symmetry.

Adding-up, this assumption means the total budget share is one $\left(\sum_{i} w_{i}=1\right)$. This assumption is related to separability concept in AIDS model. Therefore, the model parameters must meet the following restrictions:

$\sum_{i} \alpha_{i}^{*}=1 ; \sum_{i} \beta_{i}^{*}=0 ; \sum_{i} \gamma_{i j}^{*}=0, \forall j$

Homogeneity, this assumption means that the proportional changes in all prices and real incomes (expenses) do not affect on the budget share, which is expressed with the following parameter restriction:

$\sum_{j} \gamma_{i j}^{*}=0, \forall i$

Symmetry, this assumption means that consumers' preferences are consistent, which is expressed with the following parameter restriction:

$\gamma_{i j}^{*}=\gamma_{j i}^{*}, \forall i, j \gamma_{i j}^{*}=\gamma_{j i}^{*}, \forall i, j$

Stages in restricting models are as follows:

First, the unrestricted EC-LAIDS model (equation 3.2) is estimated by issuing the $3^{\text {rd }}$ equation (Malaysia) on each equations system for the seven origins.

Second, the restricted EC-LAIDS model is re-estimated by entering one by one homogeneity and symmetry restrictions (equations 3.4-3.5). 


\section{Jurnal Ekonomi Pembangunan, 17 (1), Juni 2016, 108-124}

The parameter for Malaysia equation is calculated by adding up rule (equation 3.3).

Lastly, the validity of the restriction is done to test whether the model actually fits all of the three assumption of demand theory above.

The conventional methods to test the validity of restriction, among others are: Wald test, Likelihood Ratio and Lagrange Multiplier. However, the weakness of these tests is a bias that occurs because of rejection of $\mathrm{H}_{0}\left(\mathrm{H}_{0}\right.$ : the demand system meet the assumptions), especially in conditions of multi-equation systems with relatively few observations ( $\mathrm{Li}$ et al, 2004; Wu et al, 2011). This study applies two alternative test statistics that are capable of correcting a small sample size, such as those used in the study of $\mathrm{Li}$ et al (2004) as follows:

$$
\begin{aligned}
& T_{1}=\frac{\operatorname{tr}\left(\Omega^{R}\right)^{-1}\left(\Omega^{R}-\Omega^{U}\right) / q}{\operatorname{tr}\left(\Omega^{R}\right)-1 \Omega^{U} /(n-1)(N-k)} \\
& T_{2}=\frac{\operatorname{tr}\left(\Omega^{R}\right)^{-1}\left(\Omega^{R}-\Omega^{U}\right)}{\operatorname{tr}\left(\Omega^{R}\right)-1 \Omega^{U} /(n-1)(N-k)}
\end{aligned}
$$

where:

$\Omega^{R}$ : the estimated residual covariance matrix system with restrictions (restricted)

$\Omega^{U}$ : the estimated residual covariance matrix system without restriction (unrestricted)

$N$ : Number of Observation

$n$ : Number of equations in the system

$k$ : the number of parameters to be estimated in each equation

$q$ : the number of restrictions

tr : trace matrix

The model is said to be valid fulfilling the three assumptions if the test statistics $T_{1}$ and $T_{2}$ (or one of which) worth less than the corresponding table statistics. $T_{1}$ follows the distribution of $F(q, N-k)$ and $T_{2}$ follows the distribution of $\chi_{(\mathrm{q})}^{2}$.

The EC-LAIDS model that meet the valid homogeneity and symmetry restrictions need to be tested their goodness of fit. The important one is autocorellation test. Residual system model is expected not to serial correlate with each other. Portmanteau test is applied here.
To answer the second objective of this study, the value calculation of demand elasticity is done, including price elasticity, cross-price elasticity and spending elasticity. The value of demand elasticity is obtained from the estimation of EC-LAIDS model restricted homogeneity and symmetry which is then calculated as follows:

\section{(1) Own-price elasticity}

A tourism destination is elastic if the elasticity value significantly worths more than one (in absolute terms) statistically, which means that demand on the destination is sensitive to the price changes. The smaller the elasticity value shows that the price change is not too dominant in influencing the demand to the destination; in other words, the demand is more stable.

Price elasticity value is calculated by:

$\varepsilon_{i i}=\frac{\gamma_{i i}^{*}}{w_{i}}-\beta_{i}^{*}-1$

The variance of price elasticity value is calculated by:

$$
\operatorname{var}\left(\varepsilon_{i i}\right)=\frac{\operatorname{var}\left(\gamma_{i i}^{*}\right)}{w_{i}^{2}}+\operatorname{var}\left(\beta_{i}^{*}\right)
$$

Test statistics for price elasticity value is calculated by:

$$
t\left(\varepsilon_{i i}\right)=\frac{\varepsilon_{i i}}{\sqrt{\operatorname{var}\left(\varepsilon_{i i}\right)}}
$$

\section{(2) Cross-price Elasticity}

Cross-price elasticity indicates substitution or complementary effects that are used to analyze the competitiveness of Indonesia against competitors. Positive value shows substitution relationship while negative value shows complementary relationship. Cross-price elasticity values is calculated by:

$\varepsilon_{i j}=\frac{\gamma_{i i}^{*}}{w_{i}}-\beta_{i}^{*} \frac{w_{j}}{w_{i}}$

The variance of cross-price elasticity value is calculated by 
Jurnal Ekonomi Pembangunan, 17 (1), Juni 2016, 108-124

$\operatorname{var}\left(\varepsilon_{i j}\right)=\frac{\operatorname{var}\left(\gamma_{i i}^{*}\right)}{w_{i}^{2}}+\operatorname{var}\left(\beta_{i}^{*}\right)\left(\frac{w_{j}}{w_{i}}\right)^{2}$

Test statistics for cross-price elasticity values is calculated by

$$
t\left(\varepsilon_{i j}\right)=\frac{\varepsilon_{i j}}{\sqrt{\operatorname{var}\left(\varepsilon_{i j}\right)}}
$$

\section{(3) Expenditure Elasticity}

Expenditure elasticity of a destination that significantly worths more than one, shows that demand on the destination is sensitive to the changes in tourists' total expenditure. Positive spending elasticity shows that the destination is a normal destination; while negative spending elasticity shows that it is an inferior destination. The expenditure elasticity value is calculated by:

$$
\varepsilon_{i x}=\frac{\beta_{i}^{*}}{w_{i}}+1
$$

The Variance of the expenditure elasticity value is calculated by:

$$
\operatorname{var}\left(\varepsilon_{i x}\right)=\frac{\operatorname{var}\left(\beta_{i}^{*}\right)}{w_{i}^{2}}
$$

Test statistics for the expenditure elasticity value is calculated by:

$$
t\left(\varepsilon_{i x}\right)=\frac{\varepsilon_{i x}}{\sqrt{\operatorname{var}\left(\varepsilon_{i x}\right)}}
$$

Expenditure elasticity is identical to income elasticity, because expenditure here is a proxy of income. Elasticity significance test is done with one tailed t-test.

The data used in this study are secondary data during the periode of 2005-2012. The dependent variables used are tourists' budget share from each country of origin to the three destination countries. These variables are the ratio between the numbers of tourists' spending of a country of origin to a destination and the the total expenditure in the three destinations. According to UNWTO, tourists' spending is defined as total money spent by tourists in a tourist destination. This expenditure includes accommodation, food and beverages, recreation and entertainment, tour guide services, local travel packages, local transportation, souvenirs, health or beauty, daily necessities, money tips and other expenses. These expenditures do not include transportation cost from the country of origin to the destination country or vice versa. Crouch (1996) stated that tourists' spending is a measure of the more elastic demand compared to the number of tourists. This is because tourists tend to respond the price and income changes by changing the amount of spending (in the form of a long stay or spending per day) than by changing their decisions to travel. The focus of this study is the tourism demand elasticity; so that the appropriate demand measurement to be used is the tourists' expenditure.

The data of tourists' expenditure used in this study comes from the independent world research institutes, namely Euromonitor through the website http: //portal.euromonitor.com. The calculation conducted by Euromonitor is sourced from official data of statistics agencies or the ministries of tourism in each country (surveys conducted by the tourism ministries or statistical agencies) that are compiled with other information, such as from trade associations, trade news, research, and interviews with the tourism industry.

The independent variables used include: tourists' real expenditure per capita, relatively effective tourism price, and dummy global economic crisis. The tourists' real expenditure per capita is a proxy of tourists' income which reflects the tourists' purchasing power to the tourism goods and services being offered in a destination. This variabel is a natural logarithm of tourists' expenditure per capita deflated by the aggregate price index. The tourists' expenditure per capita of a country of origin is a ratio between the total expenditure of the origin to the total tourist visits in the three destination countries. The price index of Stone (1954) is applied in this 


\section{Jurnal Ekonomi Pembangunan, 17 (1), Juni 2016, 108-124}

study, since it is the most applied approach for an aggregate price index in the AIDS model on the previous empirical studies. The data of tourists' expenditure are sourced from Euromonitor (2012, 2013a, 2013b), while the data on the number of tourists' visits come from the World Tourism Organization (UNWTO 2013a, 2013b, 2013c, 2013d) and the Pacific Asia Travel Association (PATA).

In the context of international tourism, the price includes several components, those are the price of goods and tourism services in the destination country (the largest share of the total price paid by tourists), transportation cost between home countries and tourists' destinations as well as the effect of variations in exchange rates against the tourists' purchasing power. Morley (1994) defines the tourism price as all prices of goods and services bought by tourists in the destination country, outside the ticket price between countries of origin and destination countries. The tourism price variable used in the study is proxied by the natural logarithm of the ratio between consumer Price Index (CPI) and Real Effective Exchange Rate (REER) in the destination country to the ratio in the country of origin.

The assumption underlying the use of the CPI is the price changes consumed by tourists are in line with thze changes in the CPI value, or in other words, the pattern of tourists' expenditure is close to the pattern of average general consumption expenditure used for weighting the price in the CPI.

Relative tourism price approach using the ratio between the CPI of destination countries and the CPI of countries of origin describes a process of tourists' decision making in choosing whether to travel within the country (domestic) or travel abroad (international). In other words, domestic tourism is counted as a substitution to international tourism, or at least is used as a benchmark when a tourist plans to travel abroad (Song et al., 2010). Martin \& Witt (1987) stated that the ratio of CPI that is adjusted by the exchange rate is the right size for the tourism price. The combination between relative tourism price and the exchange rate is referred to as effective-relative tourism price variable (Durbarry \& Sinclair, 2003). According to Darvas (2012), REER is the exchange rate index which is often used to measure price competitiveness. The CPI data are sourced from the World Bank while the REER of data are sourced from Bruegel (Darvas, 2012).

This model included dummy variables to counteract the effects of the crisis on tourism demand over the period of 2005 - 2012 to three destination countries: Indonesia, Malaysia and Thailand. The Dummy variable is the global economic crisis that occurred during the period 2008 - 2009, worth 1 (one) in the period of crisis and is 0 (zero) when no crisis.

\section{Results And Analysis}

\subsection{Description}

Total tourist expenditure of the major market countries dominate more than $50 \%$ of total tourist spending in Indonesia and Malaysia. As for Thailand, tourist arrivals from other market countries such as Europe (France, Germany, Russia and Sweden), South Korea and India also contributed to the total expenditure. So that, the market shares of the seven tourist countries is only about $43 \%$ in Thailand.

The acquisition of market share for nearest distance tourists (Australia, Singapore, Malaysia, China and Japan), the highest is in Malaysia $(60 \%)$, next is Indonesia (47\%) and the lowest is in Thailand (26\%); while the market share for the long distance tourists (US and the United Kingdom) respectively by $17 \%, 6 \%$ and $3 \%$ are in Thailand, Indonesia and Malaysia.

\subsection{Econometrics Testing}

Dickey Fuller-GLS Stationarity test shows that the majority of the variables are not stationary in the levels but are stationary in the 


\section{Jurnal Ekonomi Pembangunan, 17 (1), Juni 2016, 108-124}

first distinction (first difference), or it can be said that the variable is integrated in order 1, I (1). This result is particularly apparent in the models for China, Japan and United Kingdom as tourists' countries of origin. The results of the other four models vary. In general, for the seven models, the number of stationary variables at the first distinction level is more or equal to the number of stationary variable at current level. This shows an early indication of the need for modeling the first distinction, by using variables that are stationary; to remove the stochastic trend that is potential making bias in the models estimation result. Therefore, it is necessary to use the ECLAIDS model, which is the first distinction form of the LAIDS model.

The Results of Engle-Granger cointegration test shows that the residual of unrestricted LAIDS model for the seven tourists' countries of origin is stationary at the level, with the minimum significance level of $5 \%$. This means there is a significant cointegration relationship among all the equations in each tourist's demand system. Therefore, EC-LAIDS modeling can be done.

Sample-size-corrected restriction test shows that the six EC-LAIDS models (except for model of country of origin Malaysia) separately meet the homogeneity and symmetry assumptions. While, the homogeneity and symmetry assumptions together cannot be fulfilled by the models of Australia, Singapore and US. Wuetal (2011) stated that homogeneity and symmetry assumptions are always fulfilled theoretically by each demand system, but cannot always be fulfilled empirically. There are several possibilities underlying the rejection of the assumptions, among others: the data used to estimate the equation system model are not capable of describing the tourists behavior accurately, the sampling bias because of too little observations used, and tourists' irrational behavior in allocating their spending when there is an asymmetric information. In the majority, the six EC-LAIDS models meet both assumptions, so that the model that will be analyzed further is a model with a combination of homogeneity and symmetry restrictions.

To test the goodness of fit of an econometric model, diagnostic test to the model needs to be done. One important diagnostic test for a demand system model is an autocorrelation test. Portmanteau test shows that the seven homogeneity and symmetry restricted EC-LAIDS models meet the residual non-autocorrelation assumptions at the $5 \%$ significance level. This condition means the residual model is not correlated between the equations in the demand system.

\subsection{Analysis of the Determinants}

The estimation results of tourist demand system with the homogeneity and symmetry restricted EC-LAIDS model indicates that ECT coefficient is negative and majority significant, with minimal significance at the $10 \%$ level. This means that the EC-LAIDS model is appropriate to use since the adjustment mechanism or the shortterm correction expected is possible to occur.

In General, the estimation result shows that price is the major determinant affecting tourists' spending allocation in the three destination countries. This can be seen from the coefficient value of price variable that is bigger than both the coefficients of real per capita expenditure variable and global crisis dummy variable. Nevertheless, the effects are not significant on tourists from Singapore and Malaysia. The underlying reason is the fact that the largest tourist proportion is for business purposes and visiting family in the destination countries. Besides that, the factor of geographical proximity makes tourists from both countries take it as a routine travel choice. Income factor (which is proxied by real per capita expenditures) affects tourists' spending allocation in the three destinations, except for tourists from Malaysia. Global economy crisis is also a determinant affecting the tourists' spending allocation in the three destinations, but it only significantly influences tourists from Malaysia, Japan and the United Kingdom. 
Avalaible online at http://journals.ums.ac.id

Jurnal Ekonomi Pembangunan, 17 (1), Juni 2016, 108-124

Table 1. Homogeneity and Symmetry Restricted EC-LAIDS Model Estimation

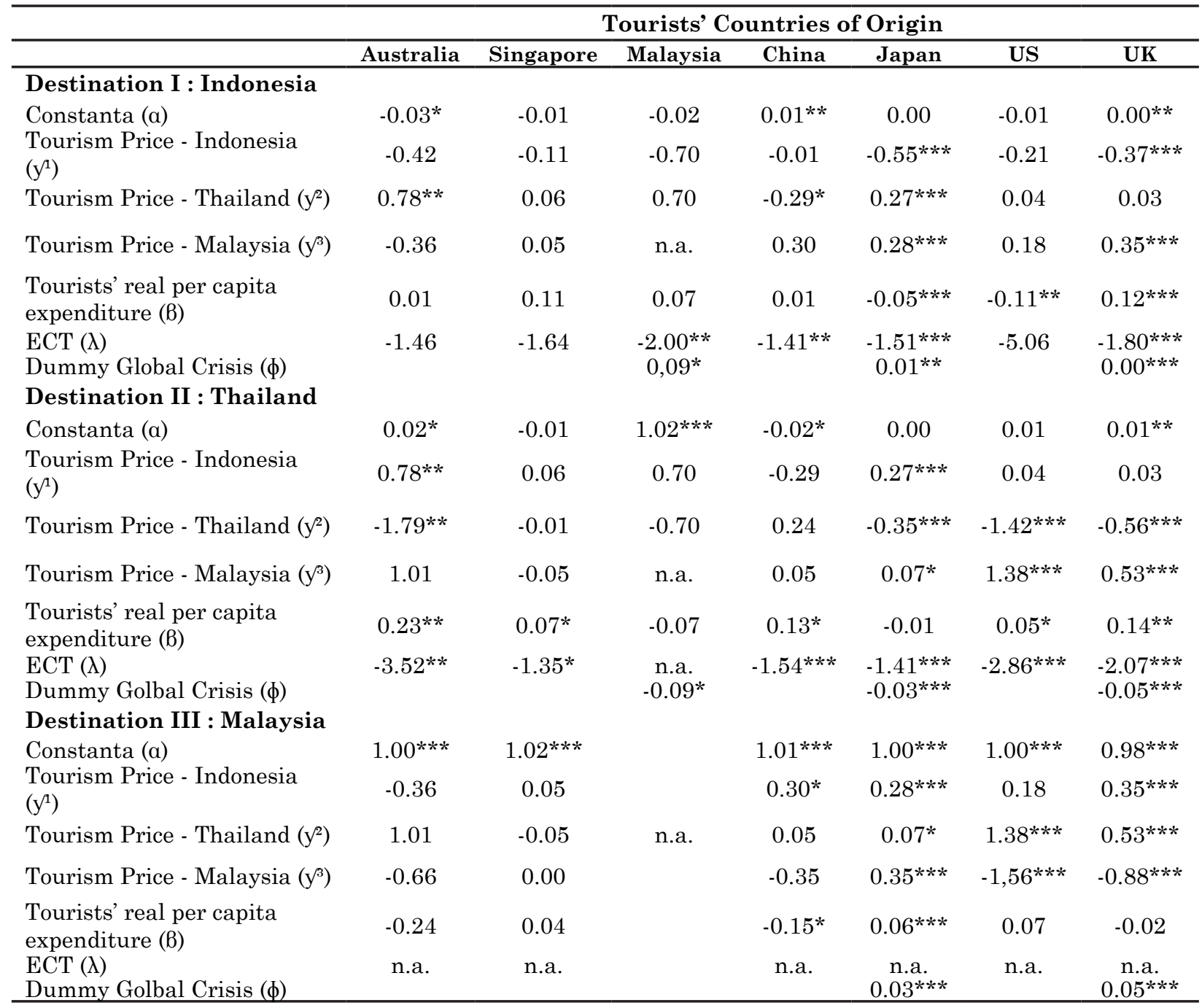

Note: ${ }^{* *}$ and $* * *$ indicate significance at the level of $10 \%, 5 \%$ and $1 \%$. Model Parameter for Malaysia as destination is calculated based on adding-up rules.

\subsection{Analysis of Demand Elasticity}

\section{a. Expenditure Elasticity}

Overall expenditure elasticity that is significant (at least at the rate of $10 \%$ ) shows a positive sign. This shows that the three destination countries: Indonesia, Thailand and Malaysia are not an inferior destination, which means that tourist demand will increase along with the increase in tourist budget (travel total budget is a proxy of tourists' income). The Expenditure elasticity value ranges between zero and two fro the three countries, which varies according to the tourists' countries of origin.
If the value of the expenditure elasticity is seen from the country of origin and destination country, then the changes in the tourists' total budget from Australia, Singapore, China and the UK will affect most on the expenditure to Thailand. Changes in tourists' total budget from the US and Japan will affect the most to the expenditure to Malaysia and changes of tourists' total budget from Malaysia will affect the most to the expenditure to Indonesia.

Interpretation of the expenditure elasticity value is exemplified in the expenditure elasticity of Indonesia and Thailand from the perspective 


\section{Jurnal Ekonomi Pembangunan, 17 (1), Juni 2016, 108-124}

of tourists from Malaysia, worth respectively 1.19 and 0.89 ; which means a $10 \%$ increase (decrease) in total budget of Malaysian tourists will increase (decrease) the tourists' expenditure to Indonesia for $11.9 \%$ and Thailand $8.9 \%$.

Table 2. Expenditure Elasticity by Country of Origin and Travelers' Destination

\begin{tabular}{lccc}
\hline $\begin{array}{c}\text { Destination/ } \\
\text { Origin }\end{array}$ & Indonesia & Thailand & Malaysia \\
\hline Australia & $1,03^{* * *}$ & $1,62^{* * *}$ & $-0,25$ \\
Singapore & 0,02 & $2,11^{* * *}$ & $1,04^{* * *}$ \\
Malaysia & $1,19^{*}$ & $0,89^{*}$ & n.a. \\
China & $1,09^{* * *}$ & $1,28^{* * *}$ & $0,61^{* * *}$ \\
Japan & $0,78^{* * *}$ & $0,99^{* * *}$ & $1,35^{* * *}$ \\
The United & 0,31 & $1,06^{* * *}$ & $1,59^{* * *}$ \\
States & & $1,21^{* * *}$ & $0,89^{* * *}$ \\
The United & $0,10^{*}$ & \multicolumn{3}{l}{} \\
Kingdom \\
$\begin{array}{l}\text { Note: *,**} \text { and }{ }^{* * *} \text { indicate significance at the level of } 10 \%, \\
5 \% \text { and } 1 \% .\end{array}$
\end{tabular}

\section{b. Price Elasticity}

Overall price elasticity that is significant (at least at the rate of $10 \%$ ) shows a negative sign. This is consistent with one of the demand theory assumptions which is the assumption of negativity; meaning that spending will decline when prices are rising. The overall price elasticity value worths less than -1 which indicates that the tourist demand to the three destinations (Indonesia, Thailand and Malaysia) are sensitive to the price changes in each of the destination.

From the standpoint of the tourists' country of origin, long-distance tourists look more sensitive than short-distance tourists. Price changes on long-distance destinations will be an incentive for tourists from US and UK to reduce their travel costs by visiting closer destinations. For close distance travelers, tourists from Australia and Japan tend to be more sensitive to price than tourists from Singapore and China. On the other side, price elasticity value of tourists from Malaysia is not significantly different from 0 (zero). Geographical proximity and visiting family as the majority of travel purpose are two factors that make the demand of Malaysian tourists to Indonesia and Thailand becomes not sensitive towards the price changes in both countries.

Price elasticities seen from origin and destination countries indicate that Japanese and Singapore tourists are the most sensitive to price changes in Indonesia. Australian tourists are most sensitive to price changes in Thailand and other travelers (US, UK and China) are most sensitive to price changes in Malaysia.

Price elasticity values seen from destination and origin countries indicate that the most sensitive travelers to price changes in Indonesia are English travelers, in Thailand are Australian travelers, and while in Malaysia are American tourists. Interpretation of price elasticity value is exemplified in price elasticity value of Indonesia from the viewpoint of British tourists at -3.66, which means a $10 \%$ decrease (increase) of tourism price in Indonesia will increase (decrease) the expenditure of British tourists to Indonesia to $36.6 \%$. This is the biggest demand changes value, comparing to the demand changes experienced by tourists of other countries; for example, Japanese tourists amounted to $33.9 \%$, the US by $21.8 \%$, Australia at $19.6 \%$, Singapore $19.2 \%$ and China $10.9 \%$.

Table 3. Price Elasticity by Country of Origin and Travelers' Destination

\begin{tabular}{lccc}
\hline $\begin{array}{c}\text { Destination/ } \\
\text { Origin }\end{array}$ & Indonesia & Thailand & Malaysia \\
\hline Australia & $-1,96^{* *}$ & $-6,18^{* * * *}$ & $-4,21$ \\
Singapore & $-1,92^{*}$ & 2,11 & $-1,04^{* * *}$ \\
Malaysia & $-2,92$ & 0,89 & n.a. \\
China & $-1,09 * *$ & $-0,60$ & $-1,79 *$ \\
Japan & $-3,39 * * *$ & $-1,57 * * *$ & $-3,12^{* * *}$ \\
The United & $-2,18^{* * *}$ & $-3,02^{* * * *}$ & $-14,57 * * *$ \\
States & $-3,66^{* * *}$ & $-1,96 * * *$ & $-5,84^{* * *}$ \\
The United & Kingdom &
\end{tabular}

Note: ${ }^{*}, * *$ and $* * *$ indicate significance at the level of $10 \%$, $5 \%$ and $1 \%$. 


\section{c. Cross-Price Elasticity}

The majority of the cross-price elasticity that is significant (at least at the rate of $10 \%$ ) shows a positive sign, indicating the substitution relationship between the three destination countries. One exception is the value of cross-price elasticity between Indonesia and Thailand from the perspective of Chinese tourists is negative, which means that Indonesia and Thailand are considered as complementary destinations for Chinese tourists.

Table 4 shows that the degree of substitution effect between any pair of the competitor destinations shows distinction (differentiation). For Chinese and British travelers, expenditure allocation to Indonesia towards price changes in Malaysia is more sensitive than the expenditure allocation to Malaysia towards price changes in Indonesia. While for Japanese travelers, expenditure allocations to Malaysia towards price changes in Indonesia is more sensitive than the expenditure allocation to Indonesia towards price changes in Malaysia, although the sensitivity difference is not too big. Japanese tourists count the expenditure allocation to Indonesia towards price changes in Thailand is more sensitive than the expenditure allocation to Thailand towards price changes in Indonesia. As for Australian tourists, both substitution effects between Indonesia and Thailand do not show significant difference, with the value of cross-price elasticity of 1.73 and 1.87 .

Interpretation of cross-price elasticity values is exemplified in the cross-price elasticity values of Indonesia and Thailand from the viewpoint of Japanese tourists which is equal to -1.34 and 0.46 , that means a $10 \%$ decrease (increase) of tourism price in Thailand will decrease (increase) Japanese tourists' spending to Indonesia by $13.4 \%$ and conversely, a $10 \%$ decrease (increase) of tourism price in Indonesia will decrease (increase) the Japanese tourists' spending to Thailand by $4.6 \%$.
Table 4. Indonesia Cross-Price Elasticity to Competitor Countries by Travelers' Origin Countries

\begin{tabular}{lcccc}
\hline $\begin{array}{c}\text { Destination/ } \\
\text { Origin }\end{array}$ & I-T & I-M & T-I & M-I \\
\hline Australia & $1,73^{* *}$ & 0,80 & $1,87^{* *}$ & 1,30 \\
Singapore & 0,60 & 1,30 & 0,81 & 0,06 \\
Malaysia & 1.73 & n.a. & 1.16 & n.a. \\
China & $1,81^{* *}$ & $1,82^{* *}$ & $-0,67^{* * *}$ & $0,87^{* *}$ \\
Japan & $1,34^{* *}$ & $1,28^{* * *}$ & $0,46^{* * *}$ & $1,55^{* * *}$ \\
The United & $0,71^{*}$ & 1.16 & 0,04 & 1.44 \\
States & $0,81^{* * *}$ & $2,75^{* * *}$ & 0,01 & $1,93^{* * *}$ \\
$\begin{array}{l}\text { The United } \\
\text { Kingdom }\end{array}$ & & & \\
\hline
\end{tabular}

Notes: $*, * *$ and $* * *$ indicate significance at the level of $10 \%$, $5 \%$ and $1 \%$.

IT: tourist demand changes in Indonesia due to price changes in Thailand.

IM: tourist demand changes in Indonesia due to price changes in Malaysia.

T-I: tourist demand changes in Thailand due to price changes in Indonesia.

M-I: tourist demand changes in Malaysia due to price changes in Indonesia.

\subsection{Analysis of Tourism Price Competitiveness}

As the ultimate goal of this research, the tourism price competitiveness of Indonesia is analyzed against two main competitor countries in Southeast Asia (Thailand and Malaysia) in relation to the three elasticity values discussed in the previous section. From the tourism perspective, travelers who are satisfied with a tourist destination tend to do repeated visits in the future; then, making the demand on that destination less sensitive towards both the fluctuation of tourists' total budget (income) and the price. Thus, from the view of tourism industry and stakeholders, the increase of tourists' satisfaction is being analogous to a reduction of its demand elasticity (Divisekera, 2003).

\subsection{Indonesia's Tourism Price Competitiveness towards Thailand}

Price elasticity values show that tourists' sensitivity to price changes vary according to 


\section{Jurnal Ekonomi Pembangunan, 17 (1), Juni 2016, 108-124}

tourists' country of origin. Most travelers (except Malaysians) are sensitive to price changes in Indonesia, while only travelers from Australia, Japan, the US and the UK which are sensitive to price changes in Thailand. Indonesia is said to be more competitive than Thailand from the viewpoints of Australia and the US tourists, because the demand of both travelers to Indonesia is not as elastics as their demand to Thailand. When tourists are satisfied at a destination, then the demand sensitivity to the destination will be reduced when there are fluctuations in the price; and this is what will improve the competitiveness position of the destination compared to competitor destinations. In contrast, Thailand is said to be more competitive than Indonesia in the eyes of Japanese and British tourists.

The cross-price elasticity values indicate that the competitiveness between Indonesia and Thailand are significant only in the tourists from Australia, China and Japan. Tourists from China consider both countries as complementary, while travelers from Australia and Japan count the countries as substitution. Japanese travelers consider Thailand as more competitive than Indonesia. If the tourism price in both countries decreases at the same percentage level, the effects on the decrease of Japanese tourists demand in competitor countries will be greater in Indonesia than in Thailand. Though, according to Australian tourists, the cross-price elasticity values between the two countries do not show significant difference; meanwhile, the high two cross-price elasticity values show that Australian travelers are having high tendency to change their tourism preferences when price fluctuation happens in competitor countries.

The competitiveness position of both countries according to travelers from Singapore and Malaysia could not be determined because the majority of elasticity values are not significant. So that, it can be concluded that the competitiveness position between Indonesia and Thailand from the viewpoints of the seven countries vary according to the characteristics of the travelers.

\subsection{Indonesia's Tourism Price Competitiveness towards Malaysia}

Price elasticity values show that tourists' sensitivity towards price changes vary according to the countries of origin. Indonesia is said to be more competitive than Malaysia according to US travelers, because the demand for Indonesia is not as elastics as their demand to Malaysia. On the other side, Malaysia is said to be more competitive than Indonesia in the eyes of tourists from Singapore and Japan.

The cross-price elasticity values indicate that the competitiveness between Indonesia and Malaysia are significant only on tourists from China, Japan and Britain. Travelers from China and the UK consider Malaysia as more competitive than Indonesia. If the tourism price in the two countries decreases by the same percentage, then, the effect on the decrease of tourist demand in competitor countries will be greater in Indonesia than in Malaysia. Meanwhile, according to Japanese travelers, the cross-price elasticity values between the two countries show no significant difference. The high both crossprice elasticity values on British tourists show a high tendency to change the tourist preferences when price fluctuations take place in competitor countries.

The Competitiveness position of both countries according to Australian travelers could not be determined because the majority of the elasticity values are not significant. Thus, it can be concluded that Malaysia has a better pricecompetitive position than Indonesia, especially from the perspective of tourists from Singapore, China, Japan and the United Kingdom.

\section{Conclusion}

The estimation results indicate that the primary determinant affecting tourists' allocation in the three destination countries is the price. However, the effect is not significant on tourists from Singapore and Malaysia. Geographical proximity is expected to be the cause of tourists from both countries become not sensitive to the 


\section{Jurnal Ekonomi Pembangunan, 17 (1), Juni 2016, 108-124}

price. Income is affecting the tourist expenditure allocation in the three destinations, except for tourists from Malaysia. The global economic crisis affects the tourist expenditure allocation in the three destinations, but the effects are only significant on tourists from Malaysia, Japan and the United Kingdom.

The expenditure elasticity values show that Indonesia, Thailand and Malaysia are normal destinations (not inferior destinations). This means that the tourist demand to the three destinations will increase along with the increase in the travelers' total budget. Price elasticity values indicate that the tourist demand is elastic (sensitive) to the price, except for tourists from Malaysia. This shows that the tourist demand to the three destinations will decrease when the price increases in these destinations; with the percentage of the decline in demand is greater than the percentage of the increase in price. The cross-price elasticity values indicate a substitution relatioinship between the three destination countries; which means travelers consider the three destinations as competitors, except for travelers from China who consider Indonesia and Thailand as a complement (complementary destinations). In general, price elasticity worths more than the expenditure elasticity; meaning that travelers demand tends to be more sensitive to the price changes than to the tourists' income changes (total budget).

The Competitiveness position between Indonesia to Thailand and Malaysia varies from the viewpoints of the seven tourist market countries. Indonesia has a better competitive position than Thailand from the viewpoints of Australian and American tourists; While Thailand has a better competitive position than Indonesia from the viewpoints of Japanese and British travelers. Indonesia has a better competitive position than Malaysia according to American travelers; While Malaysia has a better competitive position than Indonesia according to tourists from Singapore China, Japan and the United Kingdom.
The accurate pricing strategies and the stability of domestic inflation are needed to manage, since the tourism demand from the seven countries to the Indonesian market is sensitive to price.

Price trend monitoring on the competitor countries is needed, as an effort to improve the foreign exchange from Australian and British travelers; because the tourist demand from both countries is very sensitive to the price changes in the competitor countries.

Cooperation between Indonesia and Thailand in the tourism industry is recommended in order to create attractive tour packages for Chinese tourists; since Chinese tourists consider Indonesia and Thailand as a complement.

Providing great quality on tourism services and creating conducive tourism environment (eg safety factor) in order to increase tourists' satisfaction are suggested, especially for Chinese tourists (with low price elasticity tendency) as well as tourists from Singapore and Malaysia (who are not sensitive to changes in price and income ).

\section{References}

Blanke, J., \& Chiesa, T. 2013.The travel \& tourism competitiveness report 2013: reducing barriers to economic growth and job creation. Geneva, Switzerland: World Economic Forum.

Cortes-Jimenez, I., Durbarry, R., \& Pulina, M. 2009. Estimation of outbound Italian tourism demand: a monthly dynamic ECLAIDS model. Tourism Economics, 15(3), 547-565.

Crouch, G.I. 1996. Demand elasticities in international marketing: a meta-analytical application of tourism. Journal of Business Research, 36, 117-136.

Crouch, G.I. \& Ritchie, J.R.B. 1999.Tourism, competitiveness, and societal prosperity. Journal of Business Research, 44, 137-152. 


\section{Jurnal Ekonomi Pembangunan, 17 (1), Juni 2016, 108-124}

Darvas, Z. 2012. Real effective exchange rates for 178 countries: a new database. Bruegel Working Paper 2012/06. http://www.bruegel. org

De Mello, M., Pack, A., \& Sinclair, M. T. 2002.A system of equations model of UK tourism demand in neighbouring countries.Applied Economics, 34(4), 509-521.

Deaton, A. S., \& Muellbauer, J. 1980.An almost ideal demand system.American Economic Review, 70(3), 312-326.

Deluna, R Jr., \& N. Jeon. 2014. Determinants of International Tourism Demand for the Philippines: An Augmented Gravity Model Approach. Munich Personal RePEc Archive Paper No. 55294, posted 14. April 2014.

Divisekera, S. 2003.A model of demand for international tourism.Annals of Tourism Research, 30, 31-49.

Durbarry, R., \& Sinclair, M.T. 2003. Market shares analysis: the case of French tourism demand. Annals of Tourism Research, 30(4), 927-941.

Dwyer, L., Forsyth, P., \& Rao, P. 2000. The price competitiveness of travel and tourism: a comparison of 19 destinations. Tourism Management, 21(1), 9-22.

Euromonitor International (2012, August). Tourism flows inbound in Thailand. October 10, 2013. http://portal.euromonitor.com

Euromonitor International (2013a, September). Tourism flows inbound in Indonesia. October 10, 2013. http://portal.euromonitor.com

Euromonitor International (2013b, September). Tourism flows inbound in Malaysia. October 10, 2013. http://portal.euromonitor.com

Forsyth, P., \& Dwyer, L. 2009.Tourism price competitiveness.The travel \& tourism competitiveness report, chapter 1.6. World Economic Forum.
Go, F., \& Govers, R. 2000. Integrated quality management for tourist destinations: a European perspectives on achieving competitiveness. Tourism Management, 21(1), 79-88.

Li, G., Song, H., Cao, Z., \& Wu, D. C. 2013. How competitive is Hongkong against its competitors? An econometric study.Tourism Management, 36, 247-256.

Li, G., Song, H., \& Witt, S. F. 2004.Modelling tourism demand: a dynamic linear AIDS approach.Journal of Travel Research, 43, 141-150.

Lyssiotou, P. 2000. Dynamic analysis of British demand for tourism abroad.Empirical Economics, 15, 421-436.

Mangion, M., Durbarry, R., \& Sinclair, M. T. 2005. Tourism competitiveness: price and quality. Tourism Economics, 11(1), 45-68.

Martin, C., \& Witt, S. 1987. Tourism demand forecasting models: choice of appropriate variable to represent tourist's cost of living. Tourism Management, 8, 233-246.

Morley, C. L. 1994. The use of CPI for tourism prices in demand modelling. Tourism Management, 15(5), 342-346.

Moorthy, R. 2014. An Empirical Analysis of Demand Factors For Malaysian Tourism Sector Using Stochastic Methods. Review of Integrative Business \& Economics Research, Vol 3(2), 255-267.

Nachrowi, D. N., \& Usman, H. 2006. Pendekatan Populer dan Praktis Ekonometrika untuk Analisis Ekonomi dan Keuangan. Jakarta: Lembaga Penerbit Fakultas Ekonomi Universitas Indonesia.

Ritchie, J. R. B., \& Crouch, G. I. 2003.The Competitive Destination: A Sustainable Tourism Perspective. Wallingford: CABI Publishing. 


\section{Jurnal Ekonomi Pembangunan, 17 (1), Juni 2016, 108-124}

Song, H., Li, G., Witt, S. F., \& Fei, B. 2010. Tourism demand modelling and forecasting: how should demand be measured?.Tourism Economics, 16(1), 63-81.

Stone, J. R. N. 1954. Linear expenditure systems and demand analysis : an application to the pattern of British demand. Economic Journal, 64, 511-527.

Wang, K-L., \& Wu, C-S.2003. A study of competitiveness of international tourism in the Southeast Asian Region.NBER East Asia Seminar on Economics (EASE), 11, 315345. University of Chicago Press, National Bureau of Economic Research.

World Tourism Organization.2011. Tourism towards 2030/global overview.Madrid, Spain: UNWTO. http://www.unwto.org

World Tourism Organization.2013a. Compendium of tourism statistics, data 2007 - 2011, 2013
edition.Madrid, Spain: UNWTO. http://www. unwto.org

World Tourism Organization.2013b. UNWTO tourism highlights, 2013 edition.Madrid, Spain: UNWTO. http://www.unwto.org

World Tourism Organization.2013c. UNWTO world tourism barometer, volume 11, October 2013.Madrid, Spain: UNWTO. http://www. unwto.org

World Tourism Organization.2013d. Yearbook of tourism statistics, data 2007 - 2011, 2013 edition.Madrid, Spain: UNWTO. http://www. unwto.org

Wu, D. C., Li, G., \& Song, H. 2011. Analyzing tourist consumption: a dynamic systemof-equations approach.Journal of Travel Research, 50(1), 46-56. www.worldbank.org

www.pata.org 